\title{
The Genetics of Signal Transduction and the Feto- Maternal Relationship. A Study of Cytosolic Low Molecular Weight Phosphotyrosine Phosphatase
}

\author{
E. Bottini ${ }^{1, \#}$, E. Cosmi ${ }^{2}$, M. Nicotra ${ }^{2}$, \\ G. Santeusanio ${ }^{3}$, M. La Torre ${ }^{4}$, N. Bottini ${ }^{5}$ \\ and N. Lucarini ${ }^{5}$ \\ ${ }^{1}$ Chair of Preventive and Social Pediatrics, \\ University of Rome Tor Vergata, School of \\ Medicine, Rome, Italy \\ ${ }^{2}$ Institute of Obstetrics and Gynaecology, \\ University of Rome La Sapienza, School of \\ Medicine, Rome, Italy \\ ${ }^{3}$ Chair of Morbid Anatomy, University of \\ Rome Tor Vergata, School of Medicine, \\ Rome, Italy \\ ${ }^{4}$ Department of Pediatrics, Local Sanitary \\ Unit Penne, Penne, Italy \\ ${ }^{5}$ Department of MCA Biology, University of \\ Camerino, School of Science, Camerino, \\ Italy
}

\begin{abstract}
Intracellular kinases mediate positive signalling from surface receptors by phosphorylating critical target proteins whereas phosphatases inhibit this process. Differential phosphatase activity at the feto-maternal interface could determine the appropriate relative growth and development on each side of the placenta.

The highly polymorphic cytosolic low molecular weight phosphotyrosine-phosphatase (ACP1cLMWPTPase) has been studied in 170 women who had at least two consecutive spontaneous abortions along with their husbands and in 352 normal puerperae along with their newborn babies.
\end{abstract}

\footnotetext{
\# Correspondence: Egidio Bottini M.D., Università di Roma Tor Vergata, Dipartimento di Biopatologia e Diagnostica per Immagini, Via della Ricerca Scientifica, snc 00133 Roma, Italy, Fax: +39 672596028 ;

E-mail: bottini@med.uniroma2.it
}

Symmetry analysis of joint wife/husband and mother/infant distribution suggests that when ACP1 activity is lower in the mother than in either her aborted fetus or her child, the probability of abortion is higher and the survival to term is lower as compared to pairs in which the ACP1 activity is higher in the mother than in her fetus. Further analysis has shown that the effect is due to $\mathrm{S}$ isoform: i.e. a high mother/fetus $\mathrm{S}$ isoform ratio favours intrauterine survival.

Analysis of gestational duration and birth weight suggests that a high ACP1 maternal activity coupled with a low or moderate fetal activity favour fetal growth and developmental maturation.

The present data indicate that maternal-fetal genetic differences in signal transduction could contribute significantly to variability of intrauterine developmental parameters and to pathological manifestation of pregnancy.

KEYWORDS: Signal transduction, maternal-fetal relationship, ACP1, cLMW PTPase

\section{INTRODUCTION}

In the area where fetal and maternal cells come into a contact, interactions between the two cellular populations may have an important role in the development of placenta and on its pathology $[8,20]$. Maternal-fetal genetic differences within the normal variability in the structure of the receptors could determine different responses to growth factors to which both cellular populations are exposed. A similar effect could be a result of genetic differences in membrane transport and signal transduction. These mechanisms could contribute significantly to the normal variability of intrauterine developmental parameters, including the extreme 
variants that may result in pathological manifestations.

The combined action of protein kinase and phosphatases has a very important role in the post-receptorial control of cellular activities. Kinases activate the trasmission of the signal while phosphatases tend to inactivate the mechanism [15,18]. Current interest is focused on protein-tyrosine-phosphatases (PTPases) wich may influence the action of growth factors through the regulation of phosphorylation state of critical target proteins $[15,18]$. One such PTPase is the highly polymorphic cytosolic low molecular weight phosphotyrosine-phosphatase (ACP1-cLMWPTPase) [6].

ACP1 is a member of a family of low molecular weight acid phosphatases that are found in human erythrocytes, in rat liver and in other human and animal tissues. The animal enzymes have sequencies similar to the human ACP1 [4,12,13,21,32]. The human enzyme is controlled by a locus on chromosome 2 having three common alleles: $\mathrm{ACP} 1 * \mathrm{~A}, \mathrm{ACP} 1 * \mathrm{~B}$ and $\mathrm{ACP} 1 * \mathrm{C}$. There are quantitative differences in the enzymatic activity among ACP1 genotypes. Spencer et al. [27] have found the following order of allelic contributions to the enzymatic activity: $\mathrm{ACP} 1 * \mathrm{~A}<\mathrm{ACP} 1 * \mathrm{~B}<\mathrm{ACP} 1{ }^{*} \mathrm{C}$.

Each allele of ACP1 locus encodes two isozymes, the fast $(\mathrm{F})$ and the slow $(\mathrm{S})$ that are expressed in an allelic specific ratio $\mathrm{F} / \mathrm{S} 2: 1,4: 1$ and $1: 4$ for $\mathrm{ACP} 1{ }^{*} \mathrm{~A},{ }^{*} \mathrm{~B}$ and ${ }^{*} \mathrm{C}$ allele respectively [10]. Significant differences between $\mathrm{F}$ and $\mathrm{S}$ isozymes have been observed in both enzymatic and molecular properties suggesting that $\mathrm{F}$ and $\mathrm{S}$ isozymes may serve different biological functions in the cell $[7,11,28]$.

Two important functions of ACP1 have been suggested based on the experimental evidence: flavin-phosphatase activity and tyrosinephosphatase activity $[2,16,22,32]$. By catalysing the conversion of flavin-mononucleotide to riboflavin, ACP1 may play a role in regulating the cellular concentration of flavin-adenindinucleotide, flavoenzyme activity and energy metabolism. As phosphotyrosine phosphatase, the enzyme may affect the cellular growth regulation and the modulation of glycolytic rate by controlling receptor activities [25,26,30]. Given that activity variants of ACP1 are common, it is possible that this enzyme is important in regulating a large spectrum of cellular functions.

Associations of ACP1 with fertility parameters, congenital malformations and birth weight have been independently observed in different populations, suggesting a role of this enzyme in human reproduction [1,5,31].

We propose a hypothesis that genetic differences in the activity of ACP1 between the maternal and the fetal parts of the placenta may be important in the development and survival of the zygote in the uterus. Differential activation signal on either side of placenta should be appropriately balanced: if ACP1 activity in the mother is higher than in the fetus, this might favour the fetus in the sense that the fetal part of the placenta could develop relatively better as compared to the maternal part. If, instead, ACP1 activity in the mother is lower than in the fetus, this might put the fetus at a relative disadvantage since the fetal part of the placenta would be less competitive as compared to the maternal part. At both extremes of these situations the balance could be disturbed resulting in an increased susceptibility to intrauterine death and/or developmental deviations.

We have tested this hypothesis with a statistical-epidemiological approach to two distinct situations: repeated spontaneous abortions (RSA) and normal pregnancies. In a recent paper we have shown a reduced proportion of ACP $1 * \mathrm{C}$ allele in women with RSA [17].

\section{SUBJECTS AND METHODS}

\section{Repeated spontaneous abortion}

170 women who had at least two consecutive spontaneous abortions along with their husbands were examined. This condition is currently clinically classified as "repeated spontaneous abortion". Many clinicians, however, are more restrictive and prefer a cut off of at least three 
Table 1

$\mathrm{F}$ and $\mathrm{S}$ isozyme concentrations in relation to the ACP1 genotype [3]

\begin{tabular}{crcr}
\hline $\mathrm{F}$ isoform $(\mu \mathrm{g} / \mathrm{ml} \mathrm{RBC})$ & \multicolumn{2}{c}{$\mathrm{S}$ isoform $(\mu \mathrm{g} / \mathrm{ml} \mathrm{RBC})$} \\
\hline${ }^{*} \mathrm{~B} /{ }^{*} \mathrm{~B}$ & 16.4 & ${ }^{*} \mathrm{C} /{ }^{*} \mathrm{C}$ & 20.6 \\
${ }^{*} \mathrm{~A} /{ }^{*} \mathrm{~B}$ & 12.0 & ${ }^{*} \mathrm{~A} /{ }^{*} \mathrm{C}$ & 12.7 \\
${ }^{*} \mathrm{~B} /{ }^{*} \mathrm{C}$ & 11.3 & ${ }^{*} \mathrm{~B} /{ }^{*} \mathrm{C}$ & 12.1 \\
${ }^{*} \mathrm{~A} /{ }^{* \mathrm{~A}}$ & 7.9 & ${ }^{*} \mathrm{~B} /{ }^{*} \mathrm{~B}$ & 3.9 \\
${ }^{*} \mathrm{~A} /{ }^{*} \mathrm{C}$ & 7.5 & ${ }^{*} \mathrm{~A} /{ }^{*} \mathrm{~B}$ & 3.4 \\
${ }^{*} \mathrm{C} /{ }^{*} \mathrm{C}$ & 5.7 & ${ }^{*} \mathrm{~A} /{ }^{*} \mathrm{~A}$ & 3.3 \\
\hline
\end{tabular}

consecutive abortions. All subjects were seen at the Centre for Reproductive Disorders of Obstetrics and Gynaecology at the $1^{\text {st }}$ University of Rome. All clinical examinations and tests including a standard kariotype were consistently negative in the subjects included in the present sample.

\section{Normal Pregnancy}

352 puerperae along with their newborn babies were studied in the population of Penne, a small town in the Central-Eastern part of Italy. The sample was consecutive. Percentile class of birth weight was assigned according to Florence Standards [24].

ACP1 genotype was determined according to Harris and Hopkinson [19]. $\mathrm{F}$ and $\mathrm{S}$ isoforms and total enzymatic concentration (see Table 1 [3]) were assigned to ACP1 genotypes according to Dissing [10,11]. Statistical analysis was carried out using SPSS programs [23] on an IBM PC.

\section{RESULTS AND INTERPRETATIONS}

Table 2 presents the joint distribution of ACP1 genotypes among couples wife-husband (part A) with repeated spontaneous abortions and among pairs mother-child (part B) in a sample of normal pregnant women (NP). The ACP1 genotypes are ordered according to increasing activity, so that an entrance in the table above the main diagonal corresponds to a higher ACP1 activity in the husband (child) than in the wife (mother). On the other hand, an entrance below the diagonal

Table 2

Joint distribution of ACP1 genotypes among wife-husband pairs in the sample of repeated spontaneous abortions (A) and among mother-infant pairs in the sample of normal pregnancies (B). The genotypes are ordered according to increasing ACP1 enzymatic activity. The ratio of the activity in wife (mother) to the activity in husband (infant) is less than 1 for the pairs located above the main diagonal and greater than 1 for the pairs below the diagonal. The significance, $p$, is for the difference between the number of pairs located above and below the main diagonal.

\begin{tabular}{|c|c|c|c|c|c|c|}
\hline \multicolumn{7}{|c|}{ (A) Repeated spontaneous abortions } \\
\hline \multirow{6}{*}{ Wife } & & \multicolumn{4}{|c|}{ Husband } & \multirow[b]{2}{*}{$\mathrm{p}$} \\
\hline & & $* \mathrm{~A} / * \mathrm{~A}$ & $* \mathrm{~A} / * \mathrm{~B}$ & $* \mathrm{~B} / * \mathrm{~B}+{ }^{*} \mathrm{~A} /{ }^{*} \mathrm{C}$ & $* \mathrm{~B} / * \mathrm{C}$ & \\
\hline & $* \mathrm{~A} / * \mathrm{~A}$ & 1 & 5 & 11 & 1 & \multirow{4}{*}{$<0.005$} \\
\hline & $* \mathrm{~A} /{ }^{*} \mathrm{~B}$ & 1 & 18 & 46 & 4 & \\
\hline & $* \mathrm{~B} / * \mathrm{~B}+* \mathrm{~A} /{ }^{*} \mathrm{C}$ & 5 & 31 & 31 & 8 & \\
\hline & $* \mathrm{~B} /{ }^{*} \mathrm{C}$ & 0 & 2 & 2 & 4 & \\
\hline \multicolumn{7}{|c|}{ (B) Normal pregnancies } \\
\hline \multirow{6}{*}{ Mother } & & \multicolumn{4}{|c|}{ Infant } & \\
\hline & & $* \mathrm{~A} /{ }^{*} \mathrm{~A}$ & $* \mathrm{~A} / * \mathrm{~B}$ & $* \mathrm{~B} / * \mathrm{~B}+* \mathrm{~A} / * \mathrm{C}$ & $* \mathrm{~B} /{ }^{*} \mathrm{C}$ & $\mathrm{p}$ \\
\hline & $* \mathrm{~A} /{ }^{*} \mathrm{~A}$ & 17 & 15 & 3 & 0 & \multirow{4}{*}{ N.S. } \\
\hline & $* \mathrm{~A} / *^{*} \mathrm{~B}$ & 14 & 54 & 49 & 5 & \\
\hline & $* \mathrm{~B} / * \mathrm{~B}+* \mathrm{~A} / * \mathrm{C}$ & 5 & 50 & 94 & 10 & \\
\hline & $* \mathrm{~B} / * \mathrm{C}$ & 0 & 7 & 23 & 6 & \\
\hline
\end{tabular}


Table 3

Wife/husband and mother/newborn ACP1 concentration ratio in couples with RSA and in normal pregnancy. Statistical analysis has been carried out on the natural logarithm of ratio values. The mean ratio is also shown in the table. Significance refers to deviation from the expected mean value that is zero for the natural logarithm.

\begin{tabular}{|c|c|c|c|c|c|c|c|c|c|c|}
\hline & \multicolumn{5}{|c|}{ RSA } & \multicolumn{5}{|c|}{ NP } \\
\hline & \multicolumn{5}{|c|}{ ratio wife/husband } & \multicolumn{5}{|c|}{ ratio mother/newborn } \\
\hline & $\begin{array}{c}\text { mean } \ln \\
\text { ratio }\end{array}$ & S.E. & $\begin{array}{c}\text { mean } \\
\text { ratio }\end{array}$ & $\begin{array}{c}\text { no. of } \\
\text { couples }\end{array}$ & $\mathrm{p}$ & $\begin{array}{l}\text { mean } \ln \\
\text { ratio }\end{array}$ & S.E. & $\begin{array}{l}\text { mean } \\
\text { ratio }\end{array}$ & $\begin{array}{l}\text { no. of } \\
\text { couples }\end{array}$ & $\mathrm{p}$ \\
\hline $\begin{array}{l}\text { Total enzyme } \\
\text { concentration }\end{array}$ & -0.07 & 0.021 & 0.93 & 170 & $\cong 0.001$ & 0.03 & 0.012 & 1.03 & 352 & $<0.02$ \\
\hline $\mathrm{F}$ isoform & -0.02 & 0.025 & 0.98 & 170 & N.S. & 0.00 & 0.013 & 1.00 & 352 & N.S. \\
\hline $\mathrm{S}$ isoform & -0.12 & 0.035 & 0.89 & 170 & $<0.001$ & 0.06 & 0.023 & 1.06 & 352 & $\cong 0.01$ \\
\hline
\end{tabular}

corresponds to the higher ACP1 activity in the wife (mother) than in the husband (child). There are 75 and 41 pairs above and below the diagonal, respectively, in he RSA sample, and 82 and 99 such pairs in the NP sample. A reliable history of previous spontaneous abortions was obtained in 185 women of NP sample. Six reported two abortions and only one three abortions. 166 had a negative history and in this group 40 were above and 47 below the diagonal. In interpreting the observations on the couples with repeated abortions, we assume that the wife-husband differences correspond on the average to the similar mother-aborted fetuses differences.

Assuming that both samples are in HardyWeinberg equilibrium, the distributions in the table should be symmetrical around the diagonal. Yet, the distribution among the couples with repeated abortions shows a strong prevalence for the triangle above the diagonal, while among the mother-child pairs, the asymmetry goes in the opposite direction, although the deviation from the expected symmetry is not statistically significant.

Since the entries above the diagonal correspond to ACP1 activity lower in the mother than in either her aborted fetus or her child, the observed asymmetries suggest that in such a situation, the probability of abortion is higher and the survival to the term is lower as compared to pairs in which the ACP1 activity is higher in the mother than in her fetus. It can be noted that a lower activity of ACP1 in most cases corresponds to a greater efficiency in the signal transduction because of a slower dephosphorylation of the activated proteins.

Table 3 shows the wife/husband and the mother/newborn ACP1 concentration ratio in

\section{Table 4}

Joint distribution of ACP1 genotypes among wife-husband pairs in the sample of repeated spontaneous abortion (A) and among motherinfant pairs in the sample of normal pregnancies

(B). Only two categories of genotypes are considered: * $\mathrm{B} /{ }^{*} \mathrm{C}$ (highest activity) and "other". The significance, $p$, is for the difference between the number of pairs located above and below the

main diagonal. Expected number assuming Hardy-Weinberg conditions for equilibrium are shown in parentheses.

\begin{tabular}{|c|c|c|c|c|}
\hline \multicolumn{5}{|c|}{ (A) Repeated spontaneous abortion } \\
\hline \multirow{4}{*}{ Wife } & & \multicolumn{2}{|c|}{ Husband } & \multirow[b]{2}{*}{$\mathrm{p}$} \\
\hline & & other & $* \mathrm{~B} / * \mathrm{C}$ & \\
\hline & other & 149 & $13(13.91)$ & \\
\hline & $* \mathrm{~B} / * \mathrm{C}$ & $4(13.91)$ & 4 & $<0.05$ \\
\hline \multicolumn{5}{|c|}{ (B) Normal pregnancies } \\
\hline \multirow{4}{*}{ Mother } & \multirow{4}{*}{$\begin{array}{l}\text { other } \\
{ }^{*} \mathrm{~B} /{ }^{*} \mathrm{C}\end{array}$} & \multicolumn{2}{|c|}{ Infant } & \\
\hline & & other & $* \mathrm{~B} / * \mathrm{C}$ & $\mathrm{p}$ \\
\hline & & 301 & $15(17.44)$ & \\
\hline & & $30(17.44)$ & 6 & $<0.05$ \\
\hline
\end{tabular}


couples with RSA and in normal pregnancy. $\mathrm{F}$ isoform, $\mathrm{S}$ isoform and total enzyme concentration have been considered. Assuming a symmetrical distribution around the diagonal, the mean value of the ratios wife/husband or mother/child should be equal to 1 (and the natural logarithm equal to zero). A relative increase of the proportion of couples above the diagonal would result in a mean ratio less than 1 (and to a negative natural logarithm) while an increase of the proportion of couples below the diagonal would result in a mean ratio greater than 1 (and to a positive natural logarithm). The table shows that the mean ratio of total ACP1 concentration is less than 1 in RSA and more than 1 in normal pregnancy. These differences are due to $\mathrm{S}$ isoform suggesting that a high mother/fetus $\mathrm{S}$ isoform ratio favours intrauterine survival.

In Table 4 the analysis is performed comparing the $* \mathrm{~B} /{ }^{*} \mathrm{C}$ genotype (which shows high $\mathrm{S}$ isoform concentration and the highest total ACP1 activity) to all other genotypes combined. The results in Table 4 are similar to those in Table 2, except that the asymmetries of the opposite signs observed in RSA(A) and in $\mathrm{NP}(\mathrm{B})$ are both statistically significant. The table also shows (in parenthesis) the number of pairs with wife (mother) of $* \mathrm{~B} /{ }^{*} \mathrm{C}$ genotype and husband (child) of another $\left(\right.$ non $\left.* \mathrm{~B} /{ }^{*} \mathrm{C}\right)$ genotype expected assuming Hardy-Weinberg condition for equilibrium. Gene frequencies in the general population for couples with RSA, and gene frequencies equal to the average between the mothers and the infants for the sample of normal pregnancies were used for these calculations. It is seen that there is a substantial deficiency of pairs $\left({ }^{*} \mathrm{~B} /{ }^{*} \mathrm{C}\right)-\left(\right.$ non $\left.* \mathrm{~B} /{ }^{*} \mathrm{C}\right)$ in the abortion sample $(\mathrm{p}<0.01)$ and a substantial excess of the same pairs in the normal pregnancy sample $(p<0.005)$. This is in accordance with the hypothesis that a fetus is better protected in a case in which the mother has a high activity of ACP1 (and hence probably a lower efficiency of signal transduction), while the ACP1 activity of the fetus is either moderate or low.

In our sample of repeated abortions, there were 151 "primary" aborters, i.e. women in whom consecutive losses were the primary event and 19 "secondary" aborters, i.e women who have had a successful pregnancy before the series of consecutive losses [29]. The asymmetry described in Table 2 was present only among primary aborters (see Table 5). Among "primary" aborters the asymmetry is much more evident and highly significant in couples with three or more consecutive abortions. In this group, the joint wife-husband ACP1 genotype appears associated with the total number of

Table 5

Symmetry analysis in secondary and primary aborters. The significance (p) is for the difference between the number of pairs with a ratio $<1$ and the number of pairs with a ratio $>1$

\begin{tabular}{llcccc}
\hline & \multicolumn{3}{c}{ Ratio of ACP1 activity wife/husband } & & p \\
\cline { 3 - 5 } & & $>1$ & 1 & $<1$ & N.S. \\
\hline Secondary & 7 & 6 & 6 & N.S. \\
Primary & 2 abortions & 19 & 26 & 27 & $<0.001$ \\
\hline
\end{tabular}

Table 6

Birth weight and gestational duration of newborns in reciprocal joint mother-newborn ACP1 genotype

\begin{tabular}{|c|c|c|c|}
\hline mother & non $* \mathrm{~B} / * \mathrm{C}$ & $* \mathrm{~B} / * \mathrm{C}$ & significance of \\
\hline newborn & ${ }^{*} \mathrm{~B} / *^{*} \mathrm{C}$ & non $* \mathrm{~B} / * \mathrm{C}$ & difference $(p)$ \\
\hline Proportion (\%) of infants above the median & $33.3 \%$ & $69.0 \%$ & $<0.025$ \\
\hline Total no. & 15 & 29 & \\
\hline Proportion (\%) of infants with a gestational age $\geq 38$ weeks & $100 \%$ & $76.7 \%$ & $<0.05$ \\
\hline Total no. & 15 & 30 & \\
\hline
\end{tabular}


observed abortions and with the gestational duration of the aborted fetus, the latter association is more evident if considered only for the first in the series of repeated abortions. The number of abortions is higher on the average $(\mathrm{p}<0.05)$ in couples in which the ACP1 activity is higher in fathers than in mothers (wife/husband ratio $<1$ ). In this category, couples with more than three abortions constitute about $30 \%$, while in the category in which the ACP1 activity is lower in husbands than in wives as well in the category in which the activities of husbands and wives are similar, the proportion of such couples is about $15 \%$ (data not shown). The gestational duration of the first aborted fetus appears to be longer on the average in couples in which the activity is higher in fathers than in mothers, whereas the duration is practically similar for couples in the other two categories $(\mathrm{p} \sim 0.5)$ (data not shown).

In about $40 \%$ of our couples with RSA, at least a live-born infant has been recorded. In the calculation of this percentage besides "secondary" also "primary " aborters who had a live born baby after the series of consecutive abortions are included. The asymmetries of ACP1 joint wife/husband distribution are much more evident (and statistically significant) in couples without a live-born infant than in those with one or more live-born infants (data not shown).

Table 6 shows birth weight and gestational duration of newborns in relation to the joint maternal-newborn ACP1 genotype in the sample of normal pregnant women. A high maternal ACP1 activity coupled with moderate or low fetal ACP1 activity is associated with higher degree of fetal growth and lower gestational duration as compared to the reciprocal joint mother-infant ACP1 genotype (mother with low or moderate activity and fetus with high activity). The data suggest that a high ACP1 maternal activity coupled with a low or moderate fetal activity favours fetal growth and developmental maturation giving some hints to explain the increased survival rate suggested by the data in Table 4. The relationship between gestational duration and joint wife-husband (and respectively mother-infant) ACP1 genotype in normal pregnant women is similar to that observed in RSA: it may be due to a modulation of immunological reactions connected with a differential rate of signal transduction.

\section{CONCLUSIONS AND PERSPECTIVES}

Even though the data seem to favour the proposed hypothesis, the evidence at the moment is purely circumstantial. The first point that is necessary to investigate is the precise developmental stage of ACP1 activation. The enzyme is present in all tissues, including the placenta and is expressed quite early, given that it is present in the human embryo [14]. The exact moment of its appearance and, in particular, whether it is present in the trophoblast cells at the moment of the implantation of blastocyst, is not known, however.

A study of placental cell population structure in relation to the joint maternal and fetal ACP1 genotype may give more direct evidence in favour of our hypothesis. The possible role of the joint maternal and fetal ACP1 genotype in pre-eclampsia seems also worth investigation. In this relatively common disorder, cytotrophoblast invasion is shallow and uterine arteriole invasion is nearly absent, resulting in poor blood perfusion of placenta [8].

Recently, an important role of phosphotyrosine phosphatases in antibody response has been demonstrated [9]. Differences in signal transduction between mother and fetus may influence the function of lymphocyte populations, thus contributing to modulation of maternal immunological response against fetal antigens.

\section{References}

[1] Amante A., Gloria-Bottini F. and Bottini E. Intrauterine growth: association with acid phosphatase genetic polymorphism. J. Perinat. Med. 18, (1990) 175-282. 
[2] Boivin P. and Galand C. The human red cell acid phosphatase is a phosphotyrosine protein phosphatase which dephosphorylates the membrane protein band 3. Biochem. Biophys. Res. Comm. 134, (1986) 557-564.

[3] Bottini E., Gloria-Bottini F. and Borgiani P. ACP1 and human adaptability. 1. Association with common diseases: a case control study. Hum. Genet. 96, (1995) 629-637.

[4] Camici G., Manao G., Cappugi G., Modesti A., Stefani M. and Ramponi G. The complete amino acid sequence of the low molecular weight cytosolic acid phosphatase. J. Biol. Chem. 264, (1989) 2560-2567.

[5] Chakraborty R., Ferrell R.E., Barton S.A. and Schull W.J. Genetic polymorphism and fertility parameters in the Aymara of Chile and Bolivia. Ann. Hum. Genet. 50, (1986) 69-82.

[6] Chiarugi P., Cirri P., Raugei G., Camici G., Dolfi F., Berti A. and Ramponi G. PDGF receptor as a specific in vivo target for low $M$ phosphotyrosine protein phosphatase. FEBS Letters 372, (1995) 49-53.

[7] Cirri P., Fiaschi T., Chiarugi P., Camici G., manao G., Raugei G. and Ramponi G. The molecular basis of the differing kinetic behavior of the two low molecular mass phosphotyrosine protein phosphatase isoforms. J. Biol. Chem. 271, (1996) 2604-2607.

[8] Cross J.C., Werb Z. and Fisher S.J. Implantation and the placenta: key pieces of the development puzzle. Science 266, (1994) 1508-1518.

[9] De Franco A.L. and Law D.A. Tyrosine phosphatases and the antibody response. Science 268, (1995) 263-264.

[10] Dissing J. Immunochemical characterization of human red cell acid phosphatase isozymes. Biochem. Genet. 25, (1987) 901-917.

[11] Dissing J. Human "red cell" acid phosphatase (ACP1) genetic, catalytic and molecular properties. $\mathrm{PhD}$ thesis, Kobenhavn Universitet, Kobenhavn, Denmark (1993).

[12] Dissing J., Johnsen A.H. and Sensabaugh G.F. Human red cell acid phosphatase (ACP1). The amino acid sequence of the two isozymes $\mathrm{Bf}$ and Bs encoded by the ACP1*B allele. J. Biol. Chem. 266, (1991) 20619-20625.

[13] Dissing J. and Svensmark O. Human red cell acid phosphatase: purification and properties of the A, $\mathrm{B}$ and C isozymes. Biochim. Biophys. Acta 1041, (1990) 232-242.

[14] Edwards Y.H. and Hopkinson D.A. Developmental changes in the electrophoretic patterns of human enzymes and other proteins. Isozymes: Current Topics in Biological and Medical Research 1, (1977) 19-78 (Alan R. Liss, Inc., NY).

[15] Fischer E.H., Charbonneau H. and Tonks N.K. Protein tyrosine phosphatases: a diverse family of intracellular and transmembrane enzymes. Science 253, (1991) 401-406.

[16] Fuchs K.R., Shekels L. and Bernlohr D.A. Analysis of the ACP1 gene product: Classification as a FMN phosphatase. Biochem. Biophys. Res. Comm. 189, (1992) 1598-1605.

[17] Gloria-Bottini F., Nicotra M., Lucarini N., Borgiani P., La Torre M., Amante A., Gimelfarb A. and Bottini E. Phosphotyrosine-proteinphosphatases and human reproduction: an association between low molecular weight acid phosphatase (ACP1) and spontaneous abortion. Dis. Markers 12, (1996) 261-269.

[18] Goldstein B.J. Protein-tyrosine phosphatases and the regulation of insulin action. J. Cell. Biochem. 48, (1992) 33-42.

[19] Harris H. and Hopkinson D.A. Handbook of Enzyme Electrophoresis in Human Genetics, Amsterdam, North Holland (1976).

[20] Hartshorne G.M. and Edwards R.G. Role of embryonic factors in implantation: recent developments. Bailliere's Clinical Obstetrics and Gynaecology 5, (1991) 133-157.

[21] Manao G., Pazzagli L., Cirri P., Caselli A., Camici G., Cappugi G., Saeed A. and Ramponi G. Rat liver low Mr Phosphotyrosine protein phosphatase isoenzymes: purification and amino acid sequences. J. Protein. Chem. 11, (1992) 333-345.

[22] Mansfield E. and Sensabaugh G.F. Red cell acid phosphatase: modulation of activity by purines. In: Brewer G.F. (Ed) The Red Cell. New York: Lisse, (1978) 233-247.

[23] Nie N.H., Hull H.C., Jenkins J.G., Steinbrenner K. and Bent D.H. Statistical Package for the Social Sciences. Second Edition. McGraw-Hill Book Company (1975).

[24] Panero C., Romano S., Cianciulli D., Carbone C., Gizdulich P., Bettini F., Mainardi C., Vergallo G., Veneruso G., Bacicchi A. and Gracci L. Auxometric parameters and gestational age in 9751 newborns in Florence. J. Foet. Med. 3, (1983) 95-103.

[25] Ramponi G., Manao G., Camici G., Cappugi G., Ruggiero M. and Bottaro D.P. The $18 \mathrm{kDa}$ cytosolic acid phosphatase from bovine liver has phosphotyrosine phosphatase activity on the 
autophosphorylated epidermal growth factor receptor. FEBS Letters 250, (1989) 469-473.

[26] Ramponi G., Ruggiero M., Raugei G., Berti A., Modesti A.A., Degl'Innocenti D., Magnelli L., Pazzagli C., Chiarugi V.P. and Camici G. Overexpression of a synthetic phosphotyrosine protein phosphatase gene inhibits normal and transformed cell growth. Int. J. Cancer 51, (1992) 652-656.

[27] Spencer N., Hopkinson D.A. and Harris H. Quantitative differences and gene dosage in the human red cell acid phosphatase polymorphism. Nature 201, (1964) 299-300.

[28] Stefani M., Caselli A., Bucciantini M., Pazzagli L., Dolfi F., Camici G., Manao G. and Ramponi G. Dephosphorylation of tyrosine phosphorylated synthetic peptides by rat liver phosphotyrosine protein phosphatase isoenzymes. FEBS Lett. 326, (1993) 131-134.
[29] Stirrat G.M. Recurrent miscarriage I: definition and epidemiology. The Lancet 366, (1990) 673675.

[30] Vogel W., Lammers R., Huang J. and Ullrich A. Activation of a phosphotyrosine phosphatase by tyrosine phosphorylation. Science 259, (1993) 1611-1614.

[31] Ward R.D., Sarfarazi M., Azimi-Garakani C. and Beardmore J.A. Genetic polymorphism and a search for genetic influences on morbidity in the newborn. In: Hharper P.S. and Sunderland E. (Eds) Genetic and Population Studies in Wales. University of Wales Press, Cardiff (1986) 342.

[32] Wo Y.P., McCormack A.L., Shabanowitz J., Hunt D.F., Davist J.P., Mitchell G.L. and Van Etten R.L. Sequencing, cloning and expression of human red cell-type acid phosphatase, a cytosolic phosphotyrosyl protein phosphatase. J. Biol. Chem. 267, (1992) 1056-10865. 


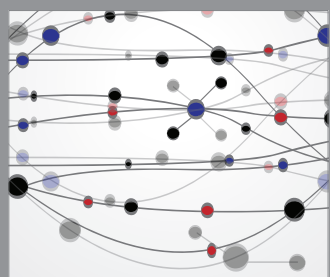

The Scientific World Journal
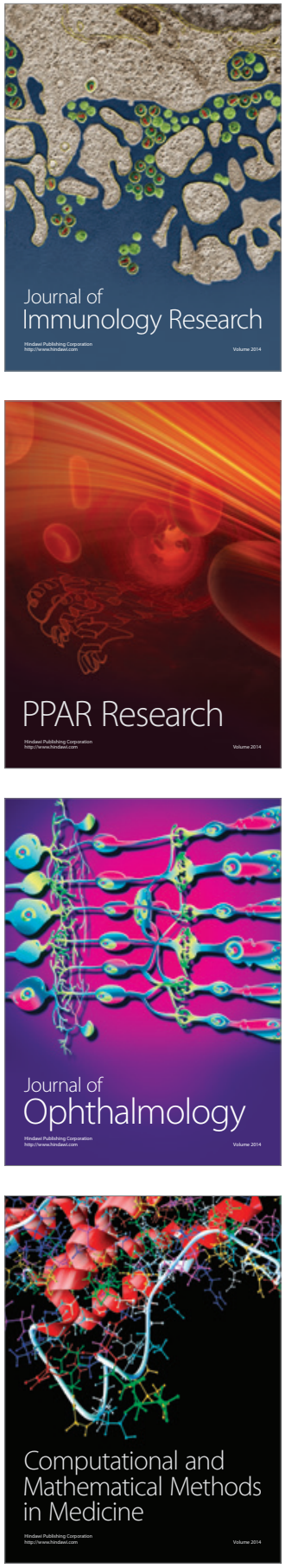

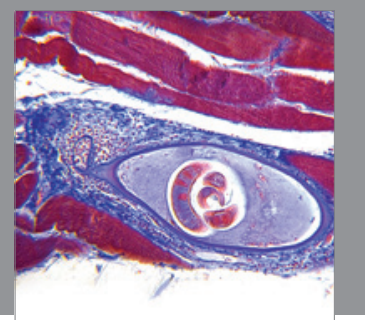

Gastroenterology

Research and Practice
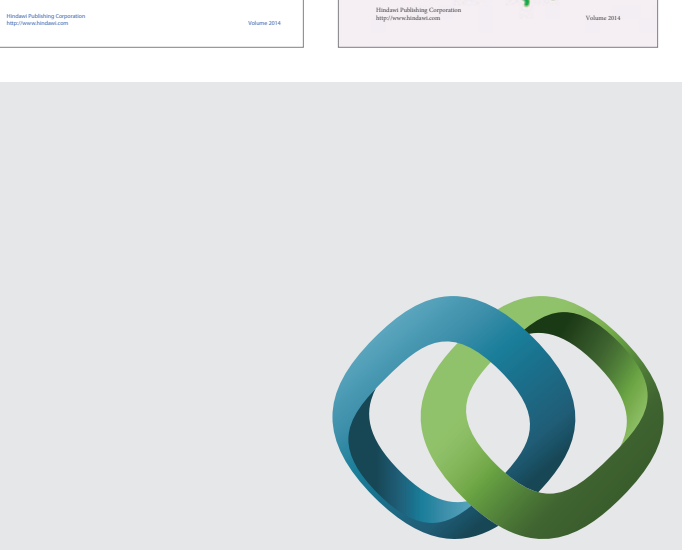

\section{Hindawi}

Submit your manuscripts at

http://www.hindawi.com
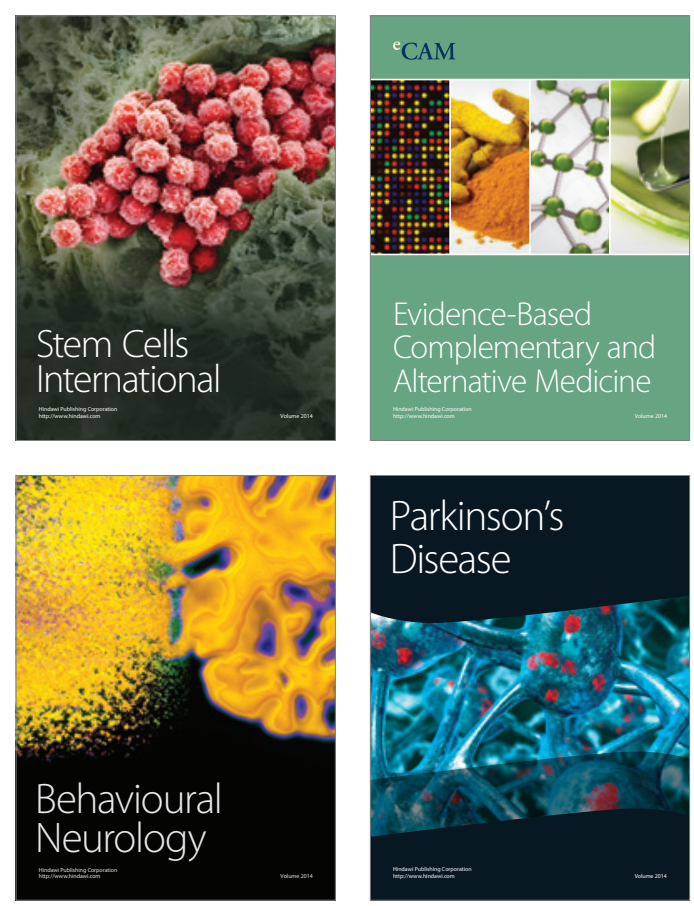

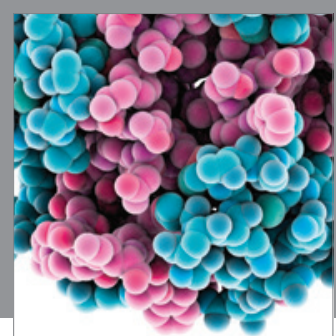

Journal of
Diabetes Research

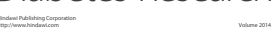

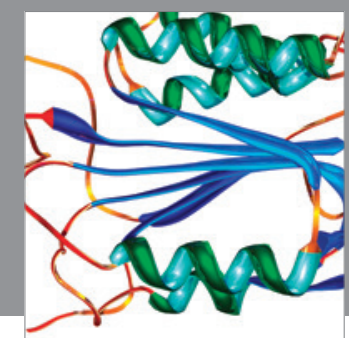

Disease Markers
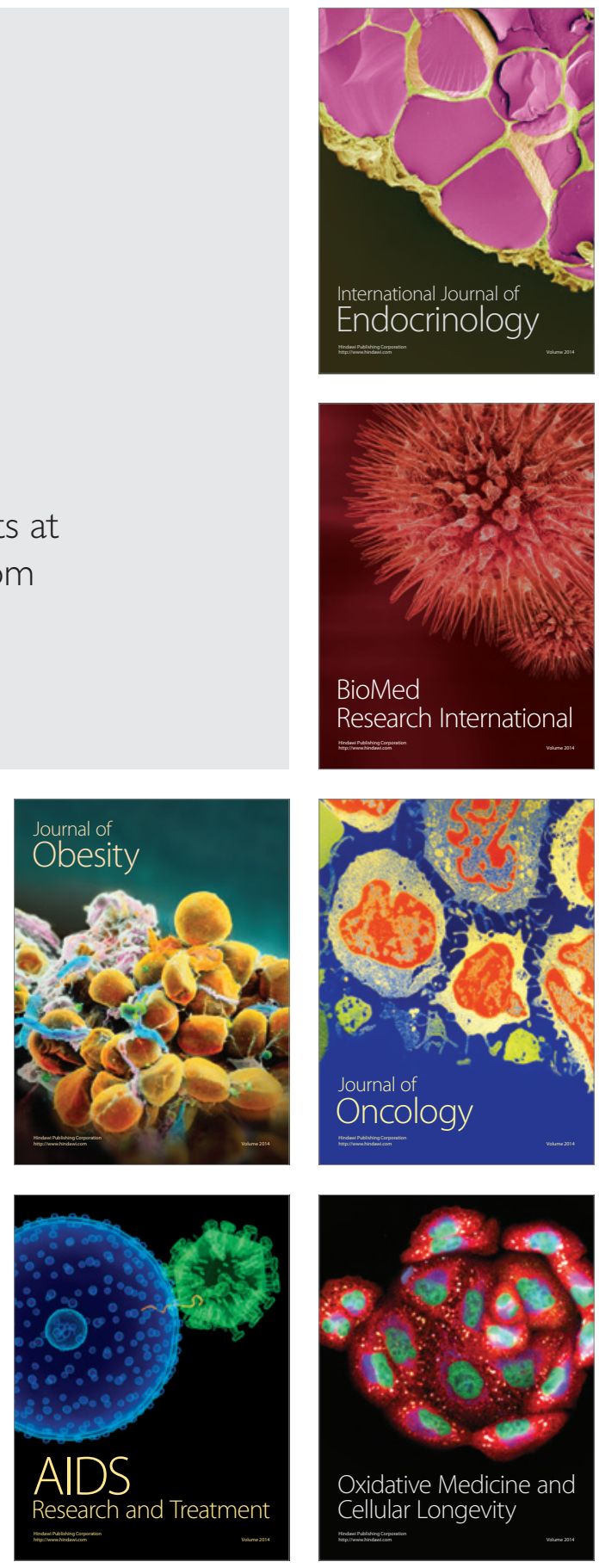